Article

\title{
Genetic Variation Underpinning ADHD Risk in a Caribbean Community
}

\author{
Pedro J. Puentes-Rozo ${ }^{1,2,+}{ }^{\circledR}$, Johan E. Acosta-López ${ }^{1} \mathbb{1}$, Martha L. Cervantes-Henríquez ${ }^{1,3}$, \\ Martha L. Martínez-Banfi ${ }^{1}$, Elsy Mejia-Segura ${ }^{1} \mathbb{D}$, Manuel Sánchez-Rojas ${ }^{1}$, \\ Marco E. Anaya-Romero ${ }^{4}$, Antonio Acosta-Hoyos 4 (D), Guisselle A. García-Llinás ${ }^{3}$, \\ Claudio A. Mastronardi ${ }^{5}$, David A. Pineda ${ }^{6,7}$, F. Xavier Castellanos ${ }^{8,9}$, \\ Mauricio Arcos-Burgos ${ }^{10, *,+}$ and Jorge I. Vélez ${ }^{3, *,+}(\mathbb{D}$ \\ 1 Grupo de Neurociencias del Caribe, Unidad de Neurociencias Cognitivas, Universidad Simón Bolívar, \\ Barranquilla 080002, Colombia \\ 2 Grupo de Neurociencias del Caribe, Universidad del Atlántico, Barranquilla 080007, Colombia \\ 3 División de Ingenierías, Universidad del Norte, Barranquilla 081007, Colombia \\ 4 Grupo de Investigación en Genética, Laboratorio de Genética y Biología Molecular, Universidad Simón \\ Bolívar, Barranquilla 080002, Colombia \\ 5 INPAC Research Group, Fundación Universitaria Sanitas, Bogotá 110211, Colombia \\ 6 Neuroscience Research Group, University of Antioquia, Medellín 050010, Colombia \\ 7 Neuropsychology and Conduct Research Group, University of San Buenaventura, Medellín 050010, \\ Colombia \\ 8 Department of Child and Adolescent Psychiatry, Hassenfeld Children's Hospital at NYU Langone, New \\ York, NY 10016, USA \\ 9 Nathan Kline Institute for Psychiatric Research, Orangeburg, NY 10962, USA \\ 10 Grupo de Investigación en Psiquiatría (GIPSI), Departamento de Psiquiatría, Instituto de Investigaciones \\ Médicas, Facultad de Medicina, Universidad de Antioquia, Medellín 050010, Colombia \\ * Correspondence: mauricio.arcos@udea.edu.co (M.A.-B.); jvelezv@uninorte.edu.co (J.I.V.) \\ + These authors contributed equally to this work.
}

Received: 8 March 2019; Accepted: 12 August 2019; Published: 16 August 2019

check for updates

\begin{abstract}
Attention Deficit Hyperactivity Disorder (ADHD) is a highly heritable and prevalent neurodevelopmental disorder that frequently persists into adulthood. Strong evidence from genetic studies indicates that single nucleotide polymorphisms (SNPs) harboured in the ADGRL3 (LPHN3), SNAP25, FGF1, DRD4, and SLC6A2 genes are associated with ADHD. We genotyped 26 SNPs harboured in genes previously reported to be associated with ADHD and evaluated their potential association in 386 individuals belonging to 113 nuclear families from a Caribbean community in Barranquilla, Colombia, using family-based association tests. SNPs rs362990-SNAP25 (T allele; $\left.p=2.46 \times 10^{-4}\right)$, rs2282794-FGF1 (A allele; $\left.p=1.33 \times 10^{-2}\right)$, rs2122642-ADGRL3 (C allele, $p=3.5 \times$ $10^{-2}$ ), and ADGRL3 haplotype CCC (markers rs1565902-rs10001410-rs2122642, OR =1.74, $P_{\text {permuted }}=$ 0.021) were significantly associated with ADHD. Our results confirm the susceptibility to ADHD conferred by SNAP25, FGF1, and ADGRL3 variants in a community with a significant African American component, and provide evidence supporting the existence of specific patterns of genetic stratification underpinning the susceptibility to ADHD. Knowledge of population genetics is crucial to define risk and predict susceptibility to disease.
\end{abstract}

Keywords: ADHD; ADGRL3; LPHN3; SNAP25; FGF1; genetics; Caribbean community; FBAT; predictive genomics 


\section{Introduction}

Attention deficit/hyperactivity disorder (ADHD) is the most common neurodevelopmental behavioural disorder that affects $\sim 5 \%$ (with figures reaching $17 \%$ ) of children and adolescents of different cohorts worldwide [1-6]. Although in some patients this condition tends to resolve by adulthood, in other cases it can persist and can have serious life-long health and socio-economic adverse consequences [7]. Affected individuals are at increased risk of poor educational achievement, low-income, underemployment, legal difficulties, and impaired social relationships [8,9]. ADHD increases the risk for disruptive (externalizing) symptoms of conduct disorder (CD), oppositional defiant disorder (ODD), and substance use disorder (SUD) [8,9].

Genetic factors are strongly implicated in the aetiology of ADHD, CD, ODD, and SUD [6,1012]. In particular, common single nucleotide polymorphisms (SNPs) harboured in the Adhesion G-protein-coupled receptor L3 (ADGRL3, also known as Latrophilin 3 or LPHN3; markers rs2345039, rs6551665, and rs1947274), the Synaptosomal-associated protein of molecular weight $25 \mathrm{kDa}(S N A P 25)$, the Fibroblast growth factor 1 (FGF1), the Solute carrier family 6 (neurotransmitter transporter, noradrenalin) member 2 (SLC6A2), and the Dopamine receptor D4 (DRD4) genes predispose one to ADHD [6,13], as confirmed by worldwide replications [2,3,6,14-21].

In this study, we explored the association of ADHD with SNPs within these genes in a family-based sample of 386 individuals ascertained from a community inhabiting the city of Barranquilla located in the Caribbean coast of Colombia. Barranquilla, with a population of $\sim 2.4$ million, is a cosmopolitan city that represents the confluence of many populations (e.g., aboriginal Amerindian, African, and a complex admixture of European (Spain), Syrian-Lebanese, Sephardic Jew, German, Italian, and English communities). These communities settled in the Atlantic coast of Colombia during the last five centuries [22] and established a pattern of genetic flow [23] that is very different from other communities in Colombia, i.e., the Paisa community [24,25] or the Andean communities surrounding Bogota [26,27]. It has been determined that the Caribbean community has one of the largest African American admixture in Colombia and in general in the Central and South American regions [28].

Our overarching goal was to evaluate the effect of genomic variants, already associated with ADHD, in the susceptibility to develop this condition in families ascertained from this Caribbean community and compare those with genomic variants predictors of ADHD in other Colombian communities. This will allow us to define specific biological predictors and study the role of genetic flow as a pivotal factor shaping the susceptibility to this neuropsychiatric disease.

\section{Subjects and Methods}

\subsection{Subjects}

We studied 386 individuals (218 (56.5\%) males and 168 (43.5\%) females) from 113 nuclear families whose members were born in the Barranquilla, Colombia, metropolitan area (Table 1). A total of 224 (58\%) individuals were diagnosed with ADHD and 162 (42\%) were diagnosed as unaffected; 94 (26.2\%) were children (6-11 years), 34 (9.4\%) adolescents (12-17 years) and $232(64.4 \%)$ adults (>18 years). No children or adults were under medication. The average family size was $3.4 \pm 0.65$ members, with $74(65.4 \%)$ trios, $33(29.2 \%)$ families with four members, 4 (3.5\%) with five members, and $2(1.8 \%)$ with six members [29]. Families belonged to the medium socio-economic stratum, with an average monthly income of $\sim$ US\$1000-3000. All individuals participated voluntarily and written informed consent was obtained from all of them either directly or from their parents (in the case of children $<18$ years old). The study was approved by the Ethics Committee of Universidad Simón Bolívar at Barranquilla, Colombia (approval \# 00032, October 13, 2011). 
Table 1. Demographic characteristics of individuals included in this study. Unaffected individuals were also ascertained from the 113 nuclear families but are clinically undiagnosed with ADHD.

\begin{tabular}{cccccc}
\hline & Affected & Unaffected & \multirow{2}{*}{ Statistic Index } & $\boldsymbol{p}$-Value & \multirow{2}{*}{ Effect Size } \\
\cline { 2 - 3 } & $\boldsymbol{n}=\mathbf{2 2 1}$ & $\boldsymbol{n}=\mathbf{1 6 5}$ & & & \\
\hline Gender & Frequency (\%) & Frequency (\%) & $\chi^{\mathbf{2}}$ & & \\
Male & $151(68.32)$ & $70(42.42)$ & 24.849 & $<0.00001$ & - \\
Female & $70(31.68)$ & $95(57.58)$ & & & \\
& Mean (SD) & Mean (SD) & Mann-Whitney's $U$ & & \\
Age & $21.4(15.31)$ & $33.9(12.69)$ & 26435 & $<0.0001$ & 0.883 \\
\hline
\end{tabular}

\subsection{Clinical Assessment}

The Grupo de Neurociencias del Caribe carried out an extensive clinical, neurological, and neuropsychological evaluation to define ADHD status and the presence of other comorbidities, using a multi-stage scheme. The full evaluation protocol is described elsewhere [30]. Briefly, we employed the Diagnostic Interview for Children and Adolescents version IV (DICA-IV) [31,32] as the gold standard to assess the diagnosis of ADHD and/or ADHD-related comorbidities including CD and ODD in children, adolescents, and adults. For children and adolescents, the DICA-IV structured interview was completed by their parents who reported children's symptoms and consequences in the academic, legal, and work-related areas, as well as alcohol and tobacco consumption, and its consequences [31-33]. This information was subsequently used to define the index case (proband). Presumptive ADHD diagnosis in childhood was assessed by obtaining a self-report retrospectively reporting on parents' behaviour during grades 1 to 11 using the DICA-IV [34]. Persistent symptoms impacting family, social, and work-related environments were also recorded. Following the $\mathrm{C}$ criteria of DSM-IV, ADHD symptoms in children and adolescents were evaluated by their parents and teachers using the Colombian version of the Behavioural Assessment System for Children (BASC) [35] and the ADHD checklist [36,37]. Initially, 124 nuclear families with at least one child affected with ADHD were sequentially ascertained from patients attending a research program in ADHD [38], advertised in the Grupo Neurociencias del Caribe's website.

\subsection{SNPs Selection, DNA Extraction, and Genotyping}

Twenty-six SNPs were selected from the ADHD gene data base (http://adhd.psych.ac.cn/) [39] as well as from previously reported associations to ADHD, ADHD endophenotypes, SUD, or ADHD comorbidities $[2,3,6,18,40]$. The full list of SNPs genotyped in this cohort is presented in Table S1 of the Supplementary Material.

Genomic DNA was isolated from blood samples using the MasterPure ${ }^{\circledR}$ DNA Purification Kit (Epicentre Biotechnologies, Chicago, IL, USA) according to the manufacturer's protocol and stored at $-80^{\circ} \mathrm{C}$. DNA concentrations were measured using a NanoDrop spectrophotometer (Thermo Fisher Scientific, Waltham, MA, USA). The integrity of DNA samples was verified via 260/280 absorbance ratios. Genotyping was performed using multiplex Sequenom ${ }^{\circledR}$ Technology on the Agena Bioscience MassARRAY ${ }^{\circledR}$ MALDI-TOF instrument at the University of Arizona Genetics Core (UAGC). Primers designed for PCR amplification and extension were prepared by the UAGC. To avoid potential biases, samples were placed randomly, and laboratory personnel were blinded to the identity and source of DNA samples.

\section{Statistical Analysis}

\subsection{Quality Control}

SNPs with a minor allele frequency $(\mathrm{MAF}) \geq 0.05$ were classified as common and as rare otherwise [41]. Rare SNPs were excluded from the analysis. Additional parameters for excluding genetic markers from the analyses included (i) deviations from Hardy-Weinberg equilibrium with 
$p$-value $<0.05 / m$, where $m$ is the number of SNPs being tested (26 in total, see Table S1 in the Supplementary Material); (ii) a minimum genotype call rate of $80 \%$ [42-45]; (iii) the presence of more than two alleles; and (iv) MAF $<0.05$. Allele and genotype frequencies were estimated using maximum likelihood. Mendelian errors, a common feature in SNP-based genotyping, were detected and subsequently corrected with the methods available in Golden Helix's ${ }^{\circledR}$ SNP variation suite (SVS) 8.4.0 (Golden Helix, Inc. Bozeman, MT, USA).

\subsection{Genetic- and Haplotype-Based Association Analyses}

Given that this cohort is comprised by nuclear families of size four $(n=33 ; 29.2 \%)$, five $(n=4$; $3.5 \%)$ and six $(n=2 ; 1.8 \%)$, and not only by trios $(n=74 ; 65.4 \%)$, we used the family-based association test (FBAT) to study the association of SNPs and ADHD. The FBAT provides a unified framework to generalize the transmission disequilibrium test (TDT) [46,47], initially proposed to disclose genetic associations based on trios information. The FBAT accounts for different genetic models, sampling of family-based ascertainment designs, disease phenotypes, missing parents, and different null hypotheses [46]. The FBAT, as implemented in the PBAT module of SVS 8.4.0, allows testing combination of phenotypes (as a group) and genotypes that have the highest power by those predicted from the parents' genotypes. As age and sex are known to impact ADHD susceptibility [48-51], both variables were included as covariates under the hypothesis of no linkage and no association. Adding these covariates substantially increases FBAT power [52,53]. Additive, dominant, recessive, and heterozygous advantage models of inheritance were explored. When testing the association between a particular biallelic marker and ADHD, using both the dominant and recessive genetic models of inheritance is equivalent to testing either of them.

The PBAT module also performs the FBAT and haplotype tests for selected combinations of phenotypes and markers on the actual patients' genotypes, both as a group and individually, automatically controlling the Type I error rate to adjust for multiple comparisons [54], and the problem of population stratification that can lead to spurious associations [46,55-58]. FBAT screening methods are minimally affected by non-causal SNPs, since the final decision is based on the FBAT statistic [59].

FBATs use affected subjects as cases, and family members, parents, or siblings as "controls" (referred to as "unaffected individuals" from now on). Furthermore, low genotype call rates are compensated by the existence of parents' genotypes, and paternity and Mendelian inconsistencies are also controlled [52,53]. All these features were essential to analyze our cohort, which includes complex family structures with multiple affected individuals and, in some cases, several probands, which introduces complex patterns of ascertainment. For interpretation purposes, the sign of the $p$-value of the FBAT indicates the direction of the effect; a positive $p$-value indicates susceptibility to ADHD, while a negative $p$-value indicates a protective effect.

Haplotype-based association analyses were also performed using the Parent TDT algorithm available in HaploView [60] including only SNPs located in the same chromosomal region.

\section{Results}

\subsection{Family-Based Association Tests}

Out of the 26 SNPs genotyped, 14 had one or more than two alleles, six had a MAF $<0.05$, and six passed filters and quality control (Table 2). The total genotyping rate was $87.9 \%$ in all samples and $88.1 \%$ in the set of markers finally included for genetic analysis (Table 2). 
Table 2. Statistics for genotyped markers passing quality control in 386 individuals segregating ADHD and belonging to 113 nuclear families from a Caribbean community.

\begin{tabular}{|c|c|c|c|c|c|c|c|}
\hline \multirow{2}{*}{ Chr } & \multirow{2}{*}{ Marker } & \multirow{2}{*}{ Position ${ }^{a}$} & \multirow{2}{*}{ Gene } & \multicolumn{4}{|c|}{ Marker Information } \\
\hline & & & & Alleles $b$ & $\mathrm{MAF}^{c}$ & HW $p$-Value & \%Genotyping \\
\hline 4 & rs1565902 & $61,542,902$ & ADGRL3 & $\mathrm{C} / \mathrm{T}$ & 0.473 & 0.048 & 89.4 \\
\hline 4 & rs10001410 & $61,608,511$ & ADGRL3 & $\mathrm{C} / \mathrm{T}$ & 0.372 & 0.841 & 92.0 \\
\hline 4 & rs2122642 & $61,832,546$ & ADGRL3 & $\mathrm{C} / \mathrm{T}$ & 0.330 & 0.326 & 91.5 \\
\hline 5 & rs2282794 & $142,602,144$ & FGF1 & G/A & 0.458 & 0.244 & 85.8 \\
\hline 11 & rs916457 & 637,014 & $D R D 4$ & C/A & 0.074 & 0.546 & 88.1 \\
\hline 20 & rs362990 & $10,295,573$ & SNAP25 & $\mathrm{T} / \mathrm{G}$ & 0.120 & 0.788 & 80.3 \\
\hline
\end{tabular}

${ }^{a}$ UCSC GRCh37/hg19 coordinates. ${ }^{b}$ Minor allele reported in bold. ${ }^{c}$ Sample-based estimate. Chr: Chromosome; MAF: Minor allele frequency; HW: Hardy-Weinberg. Additional details on these intronic markers are provided in Table S1. Note: The $p$-value for the HW disequilibrium test was calculated for the full sample.

We found that markers SNAP25-rs362990, FGF1-rs2282794, and ADGRL3-rs2122642 reached statistically significant FBAT statistics and confer susceptibility to ADHD (Table 3a). In particular, the T allele of marker SNAP25-rs362990 was found to confer susceptibility to ADHD under two different inheritance models (additive model, $p=2.46 \times 10^{-4}$; heterozygous advantage (HA) model, $p=5.21 \times$ $10^{-4}$; Table 3a). Furthermore, the two alleles of marker FGF1-rs2282794 confer susceptibility to ADHD in our cohort under three different inheritance models (A allele, dominant model $p=0.013$; G allele, recessive model, $p=0.013$; G allele, HA model, $p=0.016$; Table 3a). Finally, the $\mathrm{C}$ and $\mathrm{T}$ alleles of marker ADGRL3-rs2122642 confer susceptibility to ADHD under a recessive ( $p=0.035$; Table 3a) or dominant $(p=0.035$; Table 3a) model of inheritance, respectively.

Table 3. Results of (a) family- and (b) haplotype-based association tests for ADHD in 386 individuals belonging to 113 nuclear families from a Caribbean community.

\begin{tabular}{|c|c|c|c|c|c|c|c|c|c|c|c|}
\hline \multirow[b]{2}{*}{ Chr } & \multirow[b]{2}{*}{ Marker } & \multirow[b]{2}{*}{ Gene } & \multirow[b]{2}{*}{ Position $^{a}$} & \multicolumn{3}{|c|}{ Marker Information } & \multicolumn{5}{|c|}{ FBAT Results } \\
\hline & & & & Ref. & Observed & $\begin{array}{c}\text { (Counts) } \\
\text { [Frequency] }\end{array}$ & Allele & $\begin{array}{l}\text { Cohort } \\
\text { Frequency }\end{array}$ & $y^{\text {Model }}$ & NIF & $p$-Value \\
\hline 20 & rs362990 & SNAP25 & $10,276,221$ & A & $\mathrm{A} / \mathrm{T}$ & $\begin{array}{c}(4145 / 863) \\
{[0.828 / 0.172]}\end{array}$ & $\mathrm{T}$ & 0.094 & Additive & 55 & $2.46 \times 10^{-4}$ \\
\hline \multirow[t]{2}{*}{5} & rs2282794 & FGF1 & $141,981,709$ & G & $\mathrm{A} / \mathrm{G}$ & $\begin{array}{c}(520 / 4488) \\
{[0.104 / 0.896]}\end{array}$ & A & 0.458 & $\begin{array}{c}\text { HA } \\
\text { Dominant }\end{array}$ & $\begin{array}{l}55 \\
44\end{array}$ & $\begin{array}{c}5.21 \times 10^{-4} \\
0.013\end{array}$ \\
\hline & & & & & & & G & 0.542 & $\begin{array}{l}\text { Recessive } \\
\text { HA }\end{array}$ & $\begin{array}{l}44 \\
64\end{array}$ & $\begin{array}{l}0.013 \\
0.016\end{array}$ \\
\hline \multirow[t]{2}{*}{4} & rs2122642 & ADGRL3 & $62,698,264$ & G & $\mathrm{C} / \mathrm{T}$ & $\begin{array}{c}(2722 / 2286) \\
{[0.543 / 0.457]}\end{array}$ & $\mathrm{C}$ & 0.744 & Recessive & 45 & 0.035 \\
\hline & & & & & & & $\mathrm{T}$ & 0.256 & Dominant & 45 & 0.035 \\
\hline
\end{tabular}

(a)

\begin{tabular}{cccccccc}
\hline \multirow{2}{*}{ Markers } & Haplotype & Frequency & OR (T:U) & $x^{2}$ & \multicolumn{1}{c}{$p$-Value } & Raw & Permuted \\
\hline rs1565902-rs10001410-rs2122642 & CCC & 0.411 & $1.74(74.1: 42.5)$ & 8.5 & 0.004 & 0.021 \\
\hline
\end{tabular}

a UCSC GRCh37/hg19 coordinates. Chr: Chromosome; HA: Heterozygous advantage; NIF: Number of informative families; FBAT: Family-based association test; OR: Odds ratio; T: Transmitted; UT: Untransmitted. Permuted $p$-values were obtained using 10,000 permutations as implemented in the HaploView's ParentTDT algorithm [60]. All markers are intronic. Additional details on these markers are provided in Table S1.

\subsection{Haplotype Block within ADGRL3 Confer Susceptibility to ADHD}

We identified a haplotype block within the ADGRL3 gene that confers susceptibility to ADHD ( $p_{\text {permuted }}<0.05$, Table 3b); this block spans $189 \mathrm{~kb}$ and is comprised by markers rs 1565902 , rs10001410, and rs2122642 (Figure 1). This CCC haplotype has a frequency of $41.1 \%$ in the full sample and is $\sim 1.7$ times more likely to be present in ADHD affected individuals than in unaffected individuals from these nuclear families (Table 3b). 


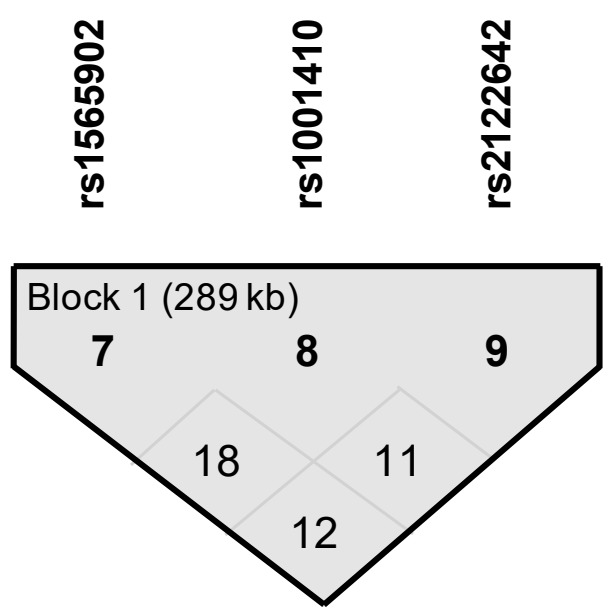

Figure 1. Linkage disequilibrium blocks for haplotype-based association analyses in 113 nuclear families segregating ADHD from a Caribbean community. See Table $3 b$ for more information.

\section{Discussion}

Family-based designs are robust against population admixture and stratification, and allow conducting complex segregation analysis and linkage and association studies that would be next to impossible in case/control-based designs [32,61-63]. With few exceptions [64-67], recent genetic studies on ADHD have primarily focused on case/control-based designs to study genetic contributions to ADHD susceptibility $[15,16,18,68-70]$.

Here we evaluated the association between ADHD and intronic SNPs harboured in, among others, the SNAP25, ADGRL3, FGF1, DRD4, and SLC6A2 genes (Table S1, Supplementary Material) in 113 nuclear families ascertained from the metropolitan area of Barranquilla, Colombia. Despite that some of the genotyped markers have been reported as associated to ADHD [71], ADHD comorbidities [72,73], and ADHD endophenotypes [40], most genetic variants associated to ADHD have mainly been identified in populations with no African American background [14,15,74-77].

We found that markers rs362990-SNAP25, rs2282794-FGF1, and rs2122642-ADGRL3 were also associated with ADHD in this set of nuclear families from the Colombian Caribbean coast (Table 3a). Moreover, we found that haplotype CCC (markers rs1565902-rs10001410-rs2122642, $p=0.021$ ) within the ADGRL3 gene confers susceptibility to ADHD in our set of nuclear families (Table 3b).

SNAP25, previously associated with ADHD and reduced expression in the prefrontal cortex [73], encodes a protein essential for synaptic vesicle fusion and neurotransmitter release and may play an important role in the synaptic function of specific neuronal systems [78]. Mutations within SNAP25 may alter the level or function of the protein and hence may have an effect on the functions of synaptic vesicle fusion and neurotransmitter release [79]. Mouse models with a deletion of SNAP25 show a hyperactive phenotype similar to ADHD in humans [80]. Although the same SNP was not genotyped in our sample, our genetic association result between a SNP harboured in SNAP25 and ADHD is consistent with a case/control study in another Colombian sample with no African American component [81], which reported that individual SNPs and a haplotype within SNAP25 were also associated with ADHD.

It is notable that SNPs in FGF1 and ADGLR3, previously reported to be associated with ADHD endophenotypes and ADHD susceptibility in the Paisa genetic isolate [6,40], were also associated with ADHD in this set of nuclear families from the Colombian Caribbean coast. FGF1 maps to 5q31.3, encodes a protein in the fibroblast growth factor (FGF) family and is expressed in key areas of the brain related to attention and activity (i.e., frontal cortex and the hippocampus) and to major depression (i.e., prefrontal cortex and the anterior cingulate cortex) [82] that may also be relevant to ADHD. The FGF family is involved in several cell survival activities including embryonic development, cell growth, morphogenesis, tissue regeneration, and tumour growth and invasion [83]. The encoded protein 
functions as a modifier of endothelial cell migration and proliferation, as well as an angiogenic factor, and has an important role in neural survival in Alzheimer's disease [84-86]. The fact that marker rs2282794-FGF1 is associated with ADHD in this Caribbean community reinforces the importance of further studying the FGF1 gene as a novel candidate gene for ADHD [40].

$A D G R L 3$ is a member the latrophilin subfamily of $G$ protein-coupled receptors and has already been implicated in ADHD susceptibility, predicting ADHD severity, disruptive behaviours comorbidity, long-term outcome, response to treatment, and SUD [2,3,6,14-21,74]. Animal models of ADHD have also provided convincing evidence of the critical role of $A D G R L 3$ in shaping the hyperactive/impulsive phenotype [87-90]. Besides further replicating the genetic contribution of these genes to ADHD, these results also suggest that these genetic effects are not unique to the Paisa community. Subsequent studies are needed to better understand how population stratification and different ethnic backgrounds, particularly African and Syrian-Lebanese, may impact ADHD susceptibility.

Altogether, our results suggest an association between SNP located in the SNAP25, FGF1, and $A D G R L 3$ genes and ADHD in this Caribbean community, which exhibits a strong genetic admixture between Aboriginal Amerindian communities with Spaniards and Africans, and later with other communities [22]. Although some clinical studies have been performed to better understand the manifestations of ADHD in individuals with an African American background [91-94], our study is the first to show that variants harbored in previously reported ADHD genes confer susceptibility to this disorder in such a population. Interestingly, this association is present when different genetic inheritance models are used (Table 3a). Future studies will include conducting complex segregation analyses to determine the inheritance mode of transmission (i.e., major gene, multifactorial contributors, or cohort effect) [10] of ADHD and comorbidities in this set of 113 families, the definition of cognitive and neuropsychological endophenotypes $[40,95,96]$, and to perform linkage and association genetic analysis between common, rare, and functional exomic variants to ADHD, ADHD comorbidities [10,18,97], and reaction times [98]. In the future, we plan to perform genetic association analyses of the already genotyped SNPs (Table S1, Supplementary Material) and ADHD comorbidities in this cohort, as well as in individuals with extreme ADHD phenotypes [3,10,29,99-102]. Further functional studies and possibly deep sequencing of these genes in this set of families could allow the identification of causal variants, and enhance translational medicine approaches to increase the accuracy of ADHD diagnosis and improve long-term outcomes.

Supplementary Materials: The following are available online at http://www.mdpi.com/2073-4409/8/8/907/s1, Table S1: Single nucleotide polymorphisms (SNPs) genotyped in 386 individuals belonging to 113 nuclear families from Barranquilla, Colombia.

Author Contributions: Conceptualization: P.J.P.-R., D.A.P.; methodology: G.A.G.-L., M.A.-B., J.I.V.; validation: P.J.P.-R., J.E.A.-L., M.L.C.-H., D.A.P., M.A.-B., J.I.V.; formal analysis: G.A.G.-L., M.A.-B., J.I.V.; investigation: P.J.P.-R., J.E.A.-L., M.L.C.-H., M.L.M.-B., E.M.-S., M.S.-R., M.E.A.-R., A.A.-H., D.A.P.; resources: P.J.P.-R., J.E.A.-L., M.E.A.-R., A.A.-H.; data curation: M.A.-B., J.I.V.; writing-original draft preparation: P.J.P.-R., F.X.C., M.A.-B., J.I.V.; writing—review \& editing: P.J.P.-R., J.E.A.-L., M.L.C.-H., M.L.M.-B., E.M.-S., M.S.-R., M.E.A.-R., A.A.-H., G.A.G.-L., C.A.M., D.A.P., F.X.C., M.A.-B., J.I.V.; visualization: M.A.-B., J.I.V.; supervision: P.J.P.-R., J.E.A.-L., C.A.M., D.A.P., F.X.C., M.A.-B., J.I.V.; project administration: P.J.P.-R., J.E.A.-L.; funding acquisition: P.J.P.-R., J.E.A.-L., M.L.C.-H., M.S.-R., D.A.P.

Funding: This study was financed by COLCIENCIAS, project "Fenotipos Complejos y Endofenotipos del Trastorno por Déficit de Atención e Hiperactividad y su Asociación con Genes Mayores y de Susceptibilidad", grant 1253-5453-1644, contract RC 384-2011. JIV is partially supported by research grant FOFICO 32101 PE0031 from Universidad del Norte, Barranquilla, Colombia. The sponsor of the study had no role in study design, data collection, data analysis, data interpretation, or writing of the paper.

Acknowledgments: We express our highest appreciation to the families enrolled in this study. M.L.C.-H. and E.M.-S. are doctoral students at Universidad del Norte, Barranquilla, Colombia, and Universidad De Flores in Buenos Aires, Argentina, respectively. Some of this work is to be presented in partial fulfilment of the requirements for the PhD degree. P.J.P.-R., M.A.-B. and J.I.V. have full access to all the data in the study, and responsible for submitting this work for publication. The authors assert that all procedures contributing to this work have been performed in accordance with the ethical standards laid down in the 1964 Declaration of Helsinki and its later amendments.

Conflicts of Interest: The authors declare no conflict of interest. 


\section{References}

1. Visser, S.; Bitsko, R.; Danielson, M.; Perou, R. Increasing prevalence of parent-reported attention-deficit/hyperactivity disorder among children-United States, 2003 and 2007. Mortal. Morb. Wkly. Rep. 2010, 59, 1439-1443.

2. Jain, M.; Velez, J.I.; Acosta, M.T.; Palacio, L.G.; Balog, J.; Roessler, E.; Pineda, D.; Londono, A.C.; Palacio, J.D.; Arbelaez, A.; et al. A cooperative interaction between lphn3 and $11 \mathrm{q}$ doubles the risk for adhd. Mol. Psychiatry 2011, 17, 741-747. [CrossRef] [PubMed]

3. Acosta, M.T.; Velez, J.I.; Bustamante, M.L.; Balog, J.Z.; Arco-Burgos, M.; Muenke, M. A two-locus genetic interaction between lphn3 and 11q predicts adhd severity and long-term outcome. Transl. Psychiatry 2011, 1, e17. [CrossRef] [PubMed]

4. Bukstein, O.G. Attention deficit hyperactivity disorder and substance use disorders. Curr. Top. Behav. Neurosci. 2012, 9, 145-172. [PubMed]

5. Pelham, W.E., Jr.; Fabiano, G.A. Evidence-based psychosocial treatments for attention-deficit/hyperactivity disorder. J. Clin. Child. Adolesc. Psychol. 2008, 37, 184-214. [CrossRef] [PubMed]

6. Arcos-Burgos, M.; Jain, M.; Acosta, M.T.; Shively, S.; Stanescu, H.; Wallis, D.; Domene, S.; Velez, J.I.; Karkera, J.D.; Balog, J.; et al. A common variant of the latrophilin 3 gene, lphn3, confers susceptibility to adhd and predicts effectiveness of stimulant medication. Mol. Psychiatry 2010, 15, 1053-1066. [CrossRef] [PubMed]

7. Sibley, M.H.; Pelham, W.E., Jr.; Molina, B.S.; Gnagy, E.M.; Waschbusch, D.A.; Garefino, A.C.; Kuriyan, A.B.; Babinski, D.E.; Karch, K.M. Diagnosing adhd in adolescence. J. Consult. Clin. Psychol. 2012, 80, 139-150. [CrossRef] [PubMed]

8. Sibley, M.H.; Pelham, W.E.; Molina, B.S.; Gnagy, E.M.; Waschbusch, D.A.; Biswas, A.; MacLean, M.G.; Babinski, D.E.; Karch, K.M. The delinquency outcomes of boys with adhd with and without comorbidity. J. Abnorm. Child. Psychol. 2011, 39, 21-32. [CrossRef] [PubMed]

9. Molina, B.S.; Pelham, W.E.; Gnagy, E.M.; Thompson, A.L.; Marshal, M.P. Attention-deficit/hyperactivity disorder risk for heavy drinking and alcohol use disorder is age specific. Alcohol Clin. Exp. Res. 2007, 31, 643-654. [CrossRef] [PubMed]

10. Jain, M.; Palacio, L.G.; Castellanos, F.X.; Palacio, J.D.; Pineda, D.; Restrepo, M.I.; Munoz, J.F.; Lopera, F.; Wallis, D.; Berg, K.; et al. Attention-deficit/hyperactivity disorder and comorbid disruptive behavior disorders: Evidence of pleiotropy and new susceptibility loci. Biol. Psychiatry 2007, 61, 1329-1339. [CrossRef] [PubMed]

11. Arcos-Burgos, M.; Castellanos, F.X.; Pineda, D.; Lopera, F.; Palacio, J.D.; Palacio, L.G.; Rapoport, J.L.; Berg, K.; Bailey-Wilson, J.E.; Muenke, M. Attention-deficit/hyperactivity disorder in a population isolate: Linkage to loci at 4q13.2, 5q33.3, 11q22, and 17p11. Am. J. Hum. Genet. 2004, 75, 998-1014. [CrossRef] [PubMed]

12. Acosta, M.T.; Arcos-Burgos, M.; Muenke, M. Attention deficit/hyperactivity disorder (adhd): Complex phenotype, simple genotype? Genet. Med. 2004, 6, 1-15. [CrossRef] [PubMed]

13. Martinez, A.F.; Muenke, M.; Arcos-Burgos, M. From the black widow spider to human behavior: Latrophilins, a relatively unknown class of g protei-coupled receptors, are implicated in psychiatric disorders. Am. J. Med. Genet. B Neuropsychiatr. Genet. 2011, 156B, 1-10. [CrossRef] [PubMed]

14. Bruxel, E.M.; Salatino-Oliveira, A.; Akutagava-Martins, G.C.; Tovo-Rodrigues, L.; Genro, J.P.; Zeni, C.P.; Polanczyk, G.V.; Chazan, R.; Schmitz, M.; Arcos-Burgos, M.; et al. Lphn3 and attention-deficit/hyperactivity disorder: A susceptibility and pharmacogenetic study. Genes Brain Behav. 2015, 14, 419-427. [CrossRef] [PubMed]

15. Gomez-Sanchez, C.I.; Riveiro-Alvarez, R.; Soto-Insuga, V.; Rodrigo, M.; Tirado-Requero, P.; Mahillo-Fernandez, I.; Abad-Santos, F.; Carballo, J.J.; Dal-Re, R.; Ayuso, C. Attention deficit hyperactivity disorder: Genetic association study in a cohort of spanish children. Behav. Brain Funct. 2016, 12, 2. [CrossRef] [PubMed]

16. Hwang, I.W.; Lim, M.H.; Kwon, H.J.; Jin, H.J. Association of lphn3 rs6551665 a/g polymorphism with attention deficit and hyperactivity disorder in korean children. Gene 2015, 566, 68-73. [CrossRef] [PubMed]

17. Ribases, M.; Ramos-Quiroga, J.A.; Sanchez-Mora, C.; Bosch, R.; Richarte, V.; Palomar, G.; Gastaminza, X.; Bielsa, A.; Arcos-Burgos, M.; Muenke, M.; et al. Contribution of lphn3 to the genetic susceptibility to adhd in adulthood: A replication study. Genes Brain Behav. 2010, 10, 149-157. [CrossRef] [PubMed] 
18. Acosta, M.T.; Swanson, J.; Stehli, A.; Molina, B.S.; Team, M.T.A.; Martinez, A.F.; Arcos-Burgos, M.; Muenke, M. Adgrl3 (lphn3) variants are associated with a refined phenotype of adhd in the mta study. Mol. Genet. Genom. Med. 2016, 4, 540-547. [CrossRef]

19. Song, J.; Kim, S.W.; Hong, H.J.; Lee, M.G.; Lee, B.W.; Choi, T.K.; Lee, S.H.; Yook, K.H. Association of snap-25, slc6a2, and lphn3 with oros methylphenidate treatment response in attention-deficit/hyperactivity disorder. Clin. Neuropharmacol. 2014, 37, 136-141. [CrossRef]

20. Labbe, A.; Liu, A.; Atherton, J.; Gizenko, N.; Fortier, M.E.; Sengupta, S.M.; Ridha, J. Refining psychiatric phenotypes for response to treatment: Contribution of lphn3 in adhd. Am. J. Med. Genet. B Neuropsychiatr. Genet. 2012, 159, 776-785. [CrossRef]

21. Fallgatter, A.J.; Ehlis, A.C.; Dresler, T.; Reif, A.; Jacob, C.P.; Arcos-Burgos, M.; Muenke, M.; Lesch, K.P. Influence of a latrophilin 3 (lphn3) risk haplotype on event-related potential measures of cognitive response control in attention-deficit hyperactivity disorder (adhd). Eur Neuropsychopharmacol. 2013, 23, 458-468. [CrossRef] [PubMed]

22. Villalón, J. Colonias Extranjeras en Barranquilla, Colombia; Ediciones Uninorte: Barranquilla, Colombia, 2008.

23. Mathias, R.A.; Taub, M.A.; Gignoux, C.R.; Fu, W.; Musharoff, S.; O'Connor, T.D.; Vergara, C.; Torgerson, D.G.; Pino-Yanes, M.; Shringarpure, S.S.; et al. A continuum of admixture in the western hemisphere revealed by the african diaspora genome. Nat. Commun. 2016, 7, 12522. [CrossRef] [PubMed]

24. Arcos-Burgos, M.; Muenke, M. Genetics of population isolates. Clin. Genet. 2002, 61, 233-247. [CrossRef] [PubMed]

25. Bravo, M.L.; Valenzuela, C.Y.; Arcos-Burgos, O.M. Polymorphisms and phyletic relationships of the paisa community from antioquia (colombia). Gene Geogr. 1996, 10, 11-17. [PubMed]

26. De Castro, M.; Restrepo, C.M. Genetics and genomic medicine in colombia. Mol. Genet. Genom. Med. 2015, 3, 84-91. [CrossRef] [PubMed]

27. Ossa, H.; Aquino, J.; Pereira, R.; Ibarra, A.; Ossa, R.H.; Perez, L.A.; Granda, J.D.; Lattig, M.C.; Groot, H.; Fagundes de Carvalho, E.; et al. Outlining the ancestry landscape of colombian admixed populations. PLoS ONE 2016, 11, e0164414. [CrossRef] [PubMed]

28. Mapa Genético de los Colombianos. Available online: http://historico.unperiodico.unal.edu.co/ediciones/ 105/15.html (accessed on 8 March 2019).

29. Pineda, D.A.; Acosta-López, J.E.; Cervantes-Henríquez, M.L.; Jimenez-Figueroa, G.; Sánchez-Rojas, M.; Pineda-Alhucema, W.; Mejía-Segura, E.; Puentes-Rozo, J. Conglomerados de clases latentes en 408 miembros de 120 familias nucleares de barranquilla con un caso índice afectado de trastorno de atención hiperactividad. Acta Neurol. Colomb. 2016, 32, 275-284. [CrossRef]

30. Cervantes-Henriquez, M.L.; Acosta-Lopez, J.E.; Martinez-Banfi, M.L.; Velez, J.I.; Mejia-Segura, E.; Lozano-Gutierrez, S.G.; Sanchez-Rojas, M.; Zurbaran, M.A.; Zurek, E.E.; Arcos-Burgos, M.; et al. Adhd endophenotypes in caribbean families. J. Atten. Disord. 2018. [CrossRef]

31. Reich, W. Diagnostic interview for children and adolescents (dica). J. Am. Acad. Child. Adolesc. Psychiatry 2000, 39, 59-66. [CrossRef]

32. Palacio, J.D.; Castellanos, F.X.; Pineda, D.A.; Lopera, F.; Arcos-Burgos, M.; Quiroz, Y.T.; Henao, G.C.; Puerta, I.C.; Ramirez, D.L.; Rapoport, J.L.; et al. Attention-deficit/hyperactivity disorder and comorbidities in 18 paisa colombian multigenerational families. J. Am. Acad. Child. Adolesc. Psychiatry 2004, 43, 1506-1515. [CrossRef]

33. Tacchini, G.; Coppola, M.T.; Musazzi, A.; Altamura, A.C.; Invernizzi, G. multinational validation of the composite international diagnostic interview (cidi). Minerva Psichiatr. 1994, 35, 63-80. [PubMed]

34. Acosta-Lopez, J.; Cervantes-Henriquez, M.L.; Jiménez-Figueroa, G.; Nunez, B.M.; Sanchez, R.M.; Puentes, R.P. Uso de una escala comportamental wender utah para evaluar en retrospectiva trastorno de atención-hiperactividad en adultos de la ciudad de barranquilla. Rev. Univ. Salud 2013, 15, 45-61.

35. Pineda, D.A.; Kamphaus, R.W.; Mora, O.; Restrepo, M.A.; Puerta, I.C.; Palacio, L.G.; Jimenez, I.; Mejia, S.; Garcia, M.; Arango, J.C.; et al. A system of multidimensional behavior assessment. A scale for parents of children from 6 to 11 years of age. Colombian version. Rev. Neurol. 1999, 28, 672-681. [PubMed]

36. APA. Diagnostic and Statistical Manual of Mental Disorders (Dsm), 4th ed.; American Psychiatric Association: Washington, DC, USA, 2000.

37. DSM-IV. Manual Diagnóstico y Estadístico de Los Trastornos Mentales: Texto Revisado; Masson: Pontarlier, France, 2002. 
38. Puentes-Rozo, P.J.; Pineda, D.A.; Acosta-López, J.E.; Cervantes-Henríquez, M.L.; Martinez-Banfi, M.L.; Jiménez-Figueroa, G.; Mejía-Segura, E.; Sánchez-Rojas, M.; Pineda-Alhucema, W.; Zurbarán, M.A.; et al. Attention Deficit/Hyperactivity Disorder and Comorbidities in 120 Nuclear Families From a Caribbean Community. Unpublished work. 2017.

39. Zhang, L.; Chang, S.; Li, Z.; Zhang, K.; Du, Y.; Ott, J.; Wang, J. Adhdgene: A genetic database for attention deficit hyperactivity disorder. Nucleic Acids Res. 2012, 40, D1003-D1009. [CrossRef] [PubMed]

40. Mastronardi, C.A.; Pillai, E.; Pineda, D.A.; Martinez, A.F.; Lopera, F.; Velez, J.I.; Palacio, J.D.; Patel, H.; Easteal, S.; Acosta, M.T.; et al. Linkage and association analysis of adhd endophenotypes in extended and multigenerational pedigrees from a genetic isolate. Mol. Psychiatry 2016, 21, 1434-1440. [CrossRef] [PubMed]

41. Bansal, V.; Libiger, O.; Torkamani, A.; Schork, N.J. Statistical analysis strategies for association studies involving rare variants. Nat. Rev. Genet. 2010, 11, 773-785. [CrossRef] [PubMed]

42. Easton, D.F.; Pooley, K.A.; Dunning, A.M.; Pharoah, P.D.; Thompson, D.; Ballinger, D.G.; Struewing, J.P.; Morrison, J.; Field, H.; Luben, R.; et al. Genome-wide association study identifies novel breast cancer susceptibility loci. Nature 2007, 447, 1087-1093. [CrossRef] [PubMed]

43. Fu, W.; Wang, Y.; Wang, Y.; Li, R.; Lin, R.; Jin, L. Missing call bias in high-throughput genotyping. BMC Genom. 2009, 10, 106. [CrossRef]

44. Hunter, D.J.; Kraft, P.; Jacobs, K.B.; Cox, D.G.; Yeager, M.; Hankinson, S.E.; Wacholder, S.; Wang, Z.; Welch, R.; Hutchinson, A.; et al. A genome-wide association study identifies alleles in fgfr2 associated with risk of sporadic postmenopausal breast cancer. Nat. Genet. 2007, 39, 870-874. [CrossRef]

45. Whittaker, P.; Bumpstead, S.; Downes, K.; Ghori, J. Snp analysis by maldi-tof mass spectrometry. In Cell Biology: A Laboratory Handbook, 3rd ed.; Celis, J., Simons, K., Small, J., Hunter, T., Shotton, D., Eds.; Elsevier: Amsterdam, The Netherlands, 2005.

46. Laird, N.M.; Horvath, S.; Xu, X. Implementing a unified approach to family-based tests of association. Genet. Epidemiol. 2000, 19, S36-S42. [CrossRef]

47. Spielman, R.S.; McGinnis, R.E.; Ewens, W.J. Transmission test for linkage disequilibrium: The insulin gene region and insulin-dependent diabetes mellitus (iddm). Am. J. Hum. Genet. 1993, 52, 506-516. [PubMed]

48. Mowlem, F.D.; Rosenqvist, M.A.; Martin, J.; Lichtenstein, P.; Asherson, P.; Larsson, H. Sex differences in predicting adhd clinical diagnosis and pharmacological treatment. Eur. Child. Adolesc. Psychiatry 2018, 28, 481-489. [CrossRef]

49. Oerbeck, B.; Overgaard, K.; Pripp, A.H.; Aase, H.; Reichborn-Kjennerud, T.; Zeiner, P. Adult adhd symptoms and satisfaction with life: Does age and sex matter? J. Atten. Disord 2019, 23, 3-11. [CrossRef] [PubMed]

50. Ramtekkar, U.P.; Reiersen, A.M.; Todorov, A.A.; Todd, R.D. Sex and age differences in attention-deficit/hyperactivity disorder symptoms and diagnoses: Implications for dsm-v and icd- 11 . J. Am. Acad. Child. Adolesc. Psychiatry 2010, 49, 217-228. [CrossRef] [PubMed]

51. Skogli, E.W.; Teicher, M.H.; Andersen, P.N.; Hovik, K.T.; Oie, M. Adhd in girls and boys-Gender differences in co-existing symptoms and executive function measures. BMC Psychiatry 2013, 13, 298. [CrossRef] [PubMed]

52. Lange, C.; Laird, N.M. On a general class of conditional tests for family-based association studies in genetics: The asymptotic distribution, the conditional power, and optimality considerations. Genet. Epidemiol. 2002, 23, 165-180. [CrossRef] [PubMed]

53. Lange, C.; Laird, N.M. Power calculations for a general class of family-based association tests: Dichotomous traits. Am. J. Hum. Genet. 2002, 71, 575-584. [CrossRef]

54. Rabinowitz, D.; Laird, N. A unified approach to adjusting association tests for population admixture with arbitrary pedigree structure and arbitrary missing marker information. Hum. Hered. 2000, 50, $211-223$. [CrossRef]

55. Benjamini, Y.; Hochberg, Y. Controlling the false discovery rate: A practical and powerful approach to multiple testing. J. R. Stat. Soc. Ser. B 1995, 57, 289-300. [CrossRef]

56. Vélez, J.I.; Correa, J.C.; Arcos-Burgos, M. A new method for detecting significant p-values with applications to genetic data. Rev. Colomb. Estad. 2014, 37, 67-76. [CrossRef]

57. Lange, C.; DeMeo, D.; Silverman, E.K.; Weiss, S.T.; Laird, N.M. Pbat: Tools for family-based association studies. Am. J. Hum. Genet. 2004, 74, 367-369. [CrossRef]

58. Lunetta, K.L.; Faraone, S.V.; Biederman, J.; Laird, N.M. Family-based tests of association and linkage that use unaffected sibs, covariates, and interactions. Am. J. Hum. Genet. 2000, 66, 605-614. [CrossRef] 
59. Xu, X.; Rakovski, C.; Xu, X.; Laird, N. An efficient family-based association test using multiple markers. Genet. Epidemiol. 2006, 30, 620-626. [CrossRef]

60. Barrett, J.C.; Fry, B.; Maller, J.; Daly, M.J. Haploview: Analysis and visualization of ld and haplotype maps. Bioinformatics 2005, 21, 263-265. [CrossRef]

61. Evangelou, E.; Trikalinos, T.A.; Salanti, G.; Ioannidis, J.P. Family-based versus unrelated case-control designs for genetic associations. PLoS Genet. 2006, 2, e123. [CrossRef]

62. Laird, N.M.; Lange, C. Family-based designs in the age of large-scale gene-association studies. Nat. Rev. Genet. 2006, 7, 385-394. [CrossRef]

63. Ott, J.; Kamatani, Y.; Lathrop, M. Family-based designs for genome-wide association studies. Nat. Rev. Genet. 2011, 12, 465-474. [CrossRef]

64. Leung, P.W.; Chan, J.K.; Chen, L.H.; Lee, C.C.; Hung, S.F.; Ho, T.P.; Tang, C.P.; Moyzis, R.K.; Swanson, J.M. Family-based association study of drd4 gene in methylphenidate-responded attention deficit/hyperactivity disorder. PLoS ONE 2017, 12, e0173748. [CrossRef]

65. Thakur, G.A.; Sengupta, S.M.; Grizenko, N.; Choudhry, Z.; Joober, R. Family-based association study of adhd and genes increasing the risk for smoking behaviours. Arch. Dis. Child. 2012, 97, 1027-1033. [CrossRef]

66. Turic, D.; Williams, H.; Langley, K.; Owen, M.; Thapar, A.; O’Donovan, M.C. A family based study of catechol-o-methyltransferase (comt) and attention deficit hyperactivity disorder (adhd). Am. J. Med. Genet. B Neuropsychiatr. Genet. 2005, 133B, 64-67. [CrossRef]

67. Neale, B.M.; Lasky-Su, J.; Anney, R.; Franke, B.; Zhou, K.; Maller, J.B.; Vasquez, A.A.; Asherson, P.; Chen, W.; Banaschewski, T.; et al. Genome-wide association scan of attention deficit hyperactivity disorder. Am. J. Med. Genet. B Neuropsychiatr. Genet. 2008, 147B, 1337-1344. [CrossRef]

68. Gu, X.; Yuan, F.F.; Huang, X.; Hou, Y.; Wang, M.; Lin, J.; Wu, J. Association of pik3cg gene polymorphisms with attention-deficit/hyperactivity disorder: A case-control study. Prog. Neuropsychopharmacol. Biol. Psychiatry 2017. [CrossRef]

69. Sanchez-Mora, C.; Richarte, V.; Garcia-Martinez, I.; Pagerols, M.; Corrales, M.; Bosch, R.; Vidal, R.; Viladevall, L.; Casas, M.; Cormand, B.; et al. Dopamine receptor drd4 gene and stressful life events in persistent attention deficit hyperactivity disorder. Am. J. Med. Genet. B Neuropsychiatr. Genet. 2015, 168, 480-491. [CrossRef]

70. Wiguna, T.; Ismail, R.I.; Winarsih, N.S.; Kaligis, F.; Hapsari, A.; Budiyanti, L.; Sekartini, R.; Rahayu, S.; Guerrero, A.P.S. Dopamine transporter gene polymorphism in children with adhd: A pilot study in indonesian samples. Asian J. Psychiatry 2017, 29, 35-38. [CrossRef]

71. Lasky-Su, J.; Banaschewski, T.; Buitelaar, J.; Franke, B.; Brookes, K.; Sonuga-Barke, E.; Ebstein, R.; Eisenberg, J.; Gill, M.; Manor, I.; et al. Partial replication of a drd4 association in adhd individuals using a statistically derived quantitative trait for adhd in a family-based association test. Biol. Psychiatry 2007, 62, 985-990. [CrossRef]

72. Brem, S.; Grunblatt, E.; Drechsler, R.; Riederer, P.; Walitza, S. The neurobiological link between ocd and adhd. Atten. Defic Hyperact. Disord. 2014, 6, 175-202. [CrossRef]

73. Hawi, Z.; Matthews, N.; Wagner, J.; Wallace, R.H.; Butler, T.J.; Vance, A.; Kent, L.; Gill, M.; Bellgrove, M.A. DNA variation in the snap25 gene confers risk to adhd and is associated with reduced expression in prefrontal cortex. PLoS ONE 2013, 8, e60274. [CrossRef]

74. Arcos-Burgos, M.; Velez, J.I.; Martinez, A.F.; Ribases, M.; Ramos-Quiroga, J.A.; Sanchez-Mora, C.; Richarte, V.; Roncero, C.; Cormand, B.; Fernandez-Castillo, N.; et al. Adgrl3 (lphn3) variants predict substance use disorder. Transl. Psychiatry 2019, 9, 42. [CrossRef]

75. Choudhry, Z.; Sengupta, S.M.; Grizenko, N.; Fortier, M.E.; Thakur, G.A.; Bellingham, J.; Joober, R. Lphn3 and attention-deficit/hyperactivity disorder: Interaction with maternal stress during pregnancy. J. Child Psychol. Psychiatry 2012, 53, 892-902. [CrossRef]

76. Kappel, D.B.; Schuch, J.B.; Rovaris, D.L.; da Silva, B.S.; Cupertino, R.B.; Winkler, C.; Teche, S.P.; Vitola, E.S.; Karam, R.G.; Rohde, L.A.; et al. Further replication of the synergistic interaction between lphn3 and the ntad gene cluster on adhd and its clinical course throughout adulthood. Prog. Neuropsychopharmacol. Biol. Psychiatry 2017, 79, 120-127. [CrossRef] 
77. Kappel, D.B.; Schuch, J.B.; Rovaris, D.L.; da Silva, B.S.; Muller, D.; Breda, V.; Teche, S.P.; Riesgo, R.S.; Schuler-Faccini, L.; Rohde, L.A.; et al. Adgrl3 rs6551665 as a common vulnerability factor underlying attention-deficit/hyperactivity disorder and autism spectrum disorder. Neuromol. Med. 2019, 21, 60-67. [CrossRef]

78. Sollner, T.; Whiteheart, S.W.; Brunner, M.; Erdjument-Bromage, H.; Geromanos, S.; Tempst, P.; Rothman, J.E. Snap receptors implicated in vesicle targeting and fusion. Nature 1993, 362, 318-324. [CrossRef]

79. Brophy, K.; Hawi, Z.; Kirley, A.; Fitzgerald, M.; Gill, M. Synaptosomal-associated protein 25 (snap-25) and attention deficit hyperactivity disorder (adhd): Evidence of linkage and association in the irish population. Mol. Psychiatry 2002, 7, 913-917. [CrossRef]

80. Hess, E.J.; Collins, K.A.; Wilson, M.C. Mouse model of hyperkinesis implicates snap-25 in behavioral regulation. J. Neurosci. 1996, 16, 3104-3111. [CrossRef]

81. Galvez, J.M.; Forero, D.A.; Fonseca, D.J.; Mateus, H.E.; Talero-Gutierrez, C.; Velez-van-Meerbeke, A. Evidence of association between snap25 gene and attention deficit hyperactivity disorder in a latin american sample. Atten. Defic. Hyperact. Disord. 2014, 6, 19-23. [CrossRef]

82. Evans, S.J.; Choudary, P.V.; Neal, C.R.; Li, J.Z.; Vawter, M.P.; Tomita, H.; Lopez, J.F.; Thompson, R.C.; Meng, F.; Stead, J.D.; et al. Dysregulation of the fibroblast growth factor system in major depression. Proc. Natl. Acad. Sci. USA 2004, 101, 15506-15511. [CrossRef]

83. Yun, Y.R.; Won, J.E.; Jeon, E.; Lee, S.; Kang, W.; Jo, H.; Jang, J.H.; Shin, U.S.; Kim, H.W. Fibroblast growth factors: Biology, function, and application for tissue regeneration. J. Tissue Eng. 2010, 2010, 218142. [CrossRef]

84. Mashayekhi, F.; Hadavi, M.; Vaziri, H.R.; Naji, M. Increased acidic fibroblast growth factor concentrations in the serum and cerebrospinal fluid of patients with alzheimer's disease. J. Clin. Neurosci. 2010, 17, 357-359. [CrossRef]

85. Tao, Q.Q.; Sun, Y.M.; Liu, Z.J.; Ni, W.; Yang, P.; Li, H.L.; Lu, S.J.; Wu, Z.Y. A variant within fgf1 is associated with alzheimer's disease in the han chinese population. Am. J. Med. Genet. B Neuropsychiatr. Genet. 2014, 165, 131-136. [CrossRef]

86. Yamagata, H.; Chen, Y.; Akatsu, H.; Kamino, K.; Ito, J.; Yokoyama, S.; Yamamoto, T.; Kosaka, K.; Miki, T.; Kondo, I. Promoter polymorphism in fibroblast growth factor 1 gene increases risk of definite alzheimer's disease. Biochem. Biophys. Res. Commun. 2004, 321, 320-323. [CrossRef]

87. Lange, M.; Norton, W.; Coolen, M.; Chaminade, M.; Merker, S.; Proft, F.; Schmitt, A.; Vernier, P.; Lesch, K.P.; Bally-Cuif, L. The adhd-susceptibility gene lphn3.1 modulates dopaminergic neuron formation and locomotor activity during zebrafish development. Mol. Psychiatry 2012, 17, 946-954. [CrossRef] [PubMed]

88. Martinez, A.F.; Abe, Y.; Hong, S.; Molyneux, K.; Yarnell, D.; Lohr, H.; Driever, W.; Acosta, M.T.; Arcos-Burgos, M.; Muenke, M. An ultraconserved brain-specific enhancer within adgrl3 (lphn3) underpins attention-deficit/hyperactivity disorder susceptibility. Biol. Psychiatry 2016, 80, 943-954. [CrossRef] [PubMed]

89. Orsini, C.A.; Setlow, B.; DeJesus, M.; Galaviz, S.; Loesch, K.; Ioerger, T.; Wallis, D. Behavioral and transcriptomic profiling of mice null for lphn3, a gene implicated in adhd and addiction. Mol. Genet. Genom. Med. 2016, 4, 322-343. [CrossRef] [PubMed]

90. Wallis, D.; Arcos-Burgos, M.; Jain, M.; Castellanos, F.X.; Palacio, J.D.; Pineda, D.; Lopera, F.; Stanescu, H.; Pineda, D.; Berg, K.; et al. Polymorphisms in the neural nicotinic acetylcholine receptor alpha4 subunit (chrna4) are associated with adhd in a genetic isolate. Atten. Defic. Hyperact. Disord. 2009, 1, 19-24. [CrossRef] [PubMed]

91. Adewuya, A.O.; Famuyiwa, O.O. Attention deficit hyperactivity disorder among nigerian primary school children: Prevalence and co-morbid conditions. Eur. Child. Adolesc. Psychiatry 2007, 16, 10-15. [CrossRef] [PubMed]

92. Miller, T.W.; Nigg, J.T.; Miller, R.L. Attention deficit hyperactivity disorder in african american children: What can be concluded from the past ten years? Clin. Psychol. Rev. 2009, 29, 77-86. [CrossRef]

93. Morgan, P.L.; Staff, J.; Hillemeier, M.M.; Farkas, G.; Maczuga, S. Racial and ethnic disparities in adhd diagnosis from kindergarten to eighth grade. Pediatrics 2013, 132, 85-93. [CrossRef]

94. Samuel, V.J.; Biederman, J.; Faraone, S.V.; George, P.; Mick, E.; Thornell, A.; Curtis, S.; Taylor, A.; Brome, D. Clinical characteristics of attention deficit hyperactivity disorder in african american children. Am. J. Psychiatry 1998, 155, 696-698. [CrossRef]

95. Castellanos, F.X.; Tannock, R. Neuroscience of attention-deficit/hyperactivity disorder: The search for endophenotypes. Nat. Rev. Neurosci. 2002, 3, 617-628. [CrossRef] 
96. Pineda, D.A.; Lopera, F.; Puerta, I.C.; Trujillo-Orrego, N.; Aguirre-Acevedo, D.C.; Hincapie-Henao, L.; Arango, C.P.; Acosta, M.T.; Holzinger, S.I.; Palacio, J.D.; et al. Potential cognitive endophenotypes in multigenerational families: Segregating adhd from a genetic isolate. Atten. Defic. Hyperact. Disord. 2011, 3 , 291-299. [CrossRef]

97. Arcos-Burgos, M.; Muenke, M. Toward a better understanding of adhd: Lphn3 gene variants and the susceptibility to develop adhd. Atten. Defic. Hyperact. Disord. 2010, 2, 139-147. [CrossRef] [PubMed]

98. Jimenez-Figueroa, G.; Ardila-Duarte, C.; Pineda, D.A.; Acosta-Lopez, J.E.; Cervantes-Henriquez, M.L.; Pineda-Alhucema, W.; Cervantes-Gutierrez, J.; Quintero-Ibarra, M.; Sanchez-Rojas, M.; Velez, J.I.; et al. Prepotent response inhibition and reaction times in children with attention deficit/hyperactivity disorder from a caribbean community. Atten. Defic. Hyperact. Disord. 2017, 9, 199-211. [CrossRef] [PubMed]

99. Barnett, I.J.; Lee, S.; Lin, X. Detecting rare variant effects using extreme phenotype sampling in sequencing association studies. Genet. Epidemiol. 2013, 37, 142-151. [CrossRef] [PubMed]

100. Emond, M.J.; Louie, T.; Emerson, J.; Zhao, W.; Mathias, R.A.; Knowles, M.R.; Wright, F.A.; Rieder, M.J.; Tabor, H.K.; Nickerson, D.A.; et al. Exome sequencing of extreme phenotypes identifies dctn 4 as a modifier of chronic pseudomonas aeruginosa infection in cystic fibrosis. Nat. Genet. 2012, 44, 886-889. [CrossRef] [PubMed]

101. Johar, A.S.; Anaya, J.M.; Andrews, D.; Patel, H.R.; Field, M.; Goodnow, C.; Arcos-Burgos, M. Candidate gene discovery in autoimmunity by using extreme phenotypes, next generation sequencing and whole exome capture. Autoimmun. Rev. 2015, 14, 204-209. [CrossRef] [PubMed]

102. Paz-Filho, G.; Boguszewski, M.C.; Mastronardi, C.A.; Patel, H.R.; Johar, A.S.; Chuah, A.; Huttley, G.A.; Boguszewski, C.L.; Wong, M.L.; Arcos-Burgos, M.; et al. Whole exome sequencing of extreme morbid obesity patients: Translational implications for obesity and related disorders. Genes 2014, 5, 709-725. [CrossRef] [PubMed]

(C) 2019 by the authors. Licensee MDPI, Basel, Switzerland. This article is an open access article distributed under the terms and conditions of the Creative Commons Attribution (CC BY) license (http://creativecommons.org/licenses/by/4.0/). 